\title{
PENERAPAN KONSEP AL-QARDH PADA KELOMPOK BANJAR DAGING DI KABUPATEN LOMBOKTENGAH
}

\author{
Rukyal Aini
}

\begin{abstract}
ABSTRAK
Hutang-piutang ini merupakan sebuah akad yang bertujuan untuk tolongmenolong, bukansebagaipengembanganmodal.Sehingga syarattambahan atau bunga yang ditetapkan baik secara pribadi maupun kesepakatan kedua belah pihak itu tidak diperbolehkan. Karena hal ini pada dasarnya tidak sesuai dengan prinsip hukum Islam. Akan tetapi kenyataannya, banyak transaksi hutang-piutang yang dilakukan masyarakat enggan untuk membayar hutang dan menganggap hutangnya adalah hal sepele. Praktek hutang-piutang yang dilakukan oleh masyarakat adalah hutangpiutang dengan bunga atau yang lebih dikenal dengan istilah anakan. Dan masyarakat sudah terbiasa dengan fenomena hutang-piutang
\end{abstract}

Kata Kunci: Hutang, Akad, Syariah.

\section{A. PENDAHULUAN}

Sebagai mahluk sosial, manusia tidak pernah terlepas dari orang lain, oleh karena itu manusia harus saling tolong-menolong dan bekerjasama antar sesama di lingkungan tempat mereka berada, karena pada dasarnya manusia diciptakan oleh Allah menjadi dua bentuk, yaitu sebagai mahluk individu dan mahluk sosial. Manusia pada dasarnya harus memenuhi kebutuhannya sehingga harus berhubungan dengan orang lain. ${ }^{1}$

Adapun penyebab terjadinya kerjasama dalam masyarakat antara lain adalah adanya kesamaan kepentingan, adanya kesulitan individu pada masyarakat dalam

${ }^{1}$ Syafiq Hanafi, Sistim Ekonomi Islam dan Kapitalisme (Yogyakarta: Cakrawala, 2007), h. 1. memenuhi kebutuhan rumah tangganya, adanya kesadaran dan kebutuhan dari masyarakat untuk terus eksis dalam lingkungan.

Kesamaan kepentingan di atas akan menyebabkan terjadinya hubungan kerja sama. Kesulitan yang sering kali dihadapi dan terjadi sejak dulu, seperti ketidak mampuan melaksanakan rumah tangga ekonomi secara layak, dalam hal ini kerja sama memegang peranan penting dan sebagai kunci bagi permasalahan dalam menghadapi kesulitan kehidupan, sehingga upaya tolong-menolong dan saling membantu dapat mewujudkan suatu masyarakat yang lebih solit dilihat dari sisi ekonomi.

Kelompok banjar merupakan kumpulan orang-orang yang 
melakukan hubungan kerja sama karena memiliki kepentingan dan kebutuhan yang sama. Dari makna kelompok banjar di atas maka setiap anggota banjar mengumpulkan barang atau uang yang bernilai sama tergantung dari yang disepakati kemudian diundi di antara mereka untuk menentukan siapa yang akan memperolehnya, undian dilakukan secara bergantian, namun undian tersebut dilakukan di hari dan waktu yang berbeda yang semua anggota pasti akan mendapatkannya. "Undi adalah sesuatu yang dipakai untuk menentukan atau memilih siapa-siapa yang berhak atas sesuatu, siapa yang bermainlebihdahuludansebagainya." ${ }^{2}$ Namun terkadang dalam sistim banjar tidak menggunakan sistim undi melainkan sistim kekeluargaan dimana anggota yang mengalami kesulitan akan diutamakan untuk mendapatkan giliran.

Di dalam kerja sama baik dalam perdagangan usaha dan lainlain, Islam memberikan dorongan dan pengarahan agar kerjasama itu berjalan pada jalan yang lurus yang sah menurut agama Islam dan diridhoi oleh Allah SWT, Maka dilarang antara pihak yang bekerjasama untuk saling menghianati, karena banyak orangorang yang melakukan kerjasama menghianatirekannya.Aturantentang

${ }^{2}$ Andini T, Nirmala dan Aditya A. Pratama, Kamus Lengkap Bahasa Indonesia (Surabaya: Prima Media, 2003), h. 46. dibolehkannya kerjasama sangat jelas, Maka tidak mengherankan bila di masyarakat banyak ditemukan berbagai macam bentuk kerjasama seperti memberikan pinjaman, utang piutang dan sistim pengumpulan uang atau barang oleh kelompok tertentu yang tidak jauh beda dengan sistim arisan yang biasa disebut dengan banjar.

Namun dalam pelaksanaannya baik dalam hal pinjam meminjam atau utang piutang (al-qardh) masih banyak orang-orang yang melakukan kegiatan tersebut tidak dilandaskan pada konsep syariat Islam, dimana para pemberi pinjaman atau utang menyulitkan pihak yang meminjam atau yang menghutang dengan memberikansyaratyangdikembalikan harus lebih dari yang dipinjam atau dihutang bahkan ada juga yang mensyaratkanharusdikembalikandua kali lipat dari yang diutang, sehingga kesulitan yang dihadapi oleh pihak yang meminjam atau yang berhutang bukan semakin ringan tapi malah semakin bertambah. Padahal dalam al-Qur'an surat al-Baqarah ayat 275 dijelaskan bahwa Allah menghalalkan jual beli dan mengharamkan riba. Kemudian pada hakekatnya pinjam meminjam atau utang piutang seharusnya menjadi bagian dari tolong-menolong antar sesama dalam masyarakat yang tidak terlepas dari sifat saling membutuhkan. 
Kaitannya dengan tolongmenolong maka, masyarakat Desa Lajut menerapkan sistim banjar daging untuk saling membantu meringankan beban ekonomi antar anggota, sehingga setiap anggota memiliki kewajiban untuk mengembalikan atau mengeluarkan daging sejumlah yang disepakati dan dalam jangka waktu yang telah ditentukan bersama.

Oleh karena itu yang menjadi focus adalah praktek kerjasama dan kesesuaiannya dengan konsep AlQardh dalam Islam.

\section{B. PEMBAHASAN}

\section{Pengertian Al-Qardh}

Qardh berasal dari kata qaradha yang artinya memotong. diartikan memotong karena orang yang memberikan utang memotong sebagian dari hartanya untuk di berikan kepada orang yang menerima utang (Muqtaridh). ${ }^{3}$

Adapun qardh secara terminologi adalah memberikan pinjaman harta kepada orang yang akan memanfaatkannya dan mengembalikangantinya dikemudian hari. ${ }^{4}$

${ }^{3}$ Ahmad Wardi Muslich, Fikih Muamalat (Jakarta:Amzah, 2015), h. 275.

${ }^{4}$ Ismail Nawawi, Fikih muamalah Klasik dan Kontemporer (Bogor: Ghalia Indonesia, 2012), h. 177.

\section{Dasar Hukum Qardh}

Firman Allah QS. AlBaqarah/2:245

Artinya : "Siapakah yang mau memberi pinjaman kepada Allah, pinjaman yang baik (menafkahkan harta dijalan Allah), maka allah akan melipat gandakan pembayaran kepadanya dengan lipatan ganda yang banyak"s

Surah At-Taghaabun Ayat 17:

Artinya: "Jika kamu meminjamkan kepada Allah pinjaman yang baik, niscaya Allah melipat gandakan balasannya kepadamu dan mengampuni kamu. dan Allah Maha pembalas Jasa lagi Maha Penyantun."

Hadis Riwayat Ibnu Mas’ud.

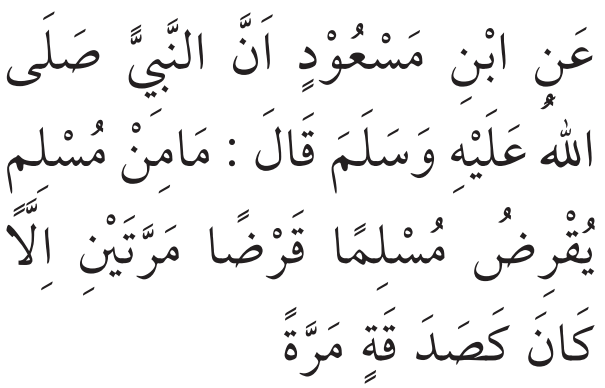

"Dan dari abu mas'ud sesungguhnya rasulallah SAW bersabda: "Seorang muslim yang mau memberikan pinjaman dua kali kepada sesama muslim, maka ibaratnya ia telah bersedakah satu

${ }^{5}$ Ibid., h. 178

${ }^{6}$ Ahmad Wardi Muslich, Fikih Muamalat, h. 275 
kali” (HR. Ibnu Majah dan Ibnu Hibban $)^{7}$

3. Implementasi Konsep AlQardh Pada Kelompok Banjar Daging

Praktek hutang-piutang merupakan bentuk praktek yang menjadi kebiasaan masyarakat dimanapun mereka berada atau bertempat tinggal yang tidakakan pernahbisa dihentikan dan tidak akan pernah dipisahkan dari kehidupan manusia, karena dengan melakukan hutang-piutang mereka dapat meringankan atau memenuhi kebutuhannya meskipun tidak menjamin sepenuhnya kebutuhan hidup terpenuhi, disebabkan banyaknya kebutuhan yang ingin dimiliki setiap individu.

Dalam kaitannya dengan hal utang-piutang, masyarakat Desa Lajut Kecamatan Praya Tengah mayoritas warganya sebagai petani, buruh tani, peternak dan pedagang. Walaupun begitu masyarakat Lajut Kecamatan Praya Tengah masih juga membutuhkan bantuan orang lain untukmenutupikekurangankebutuan sehari-hari karena pendapatan mereka tergolong minim. Dengan minimnya pendapatan atau penghasilan itu mendorong masyarakat Desa Lajut Kecamatan Praya Tengah Kabupaten LombokTengahmembentukkegiatan praktek Banjar Daging, mereka juga

${ }^{7}$ Dimyauddin Djuwaini, Pengantar Fikih Muamalah (Pustaka Pelajar 2010), h. 254 beranggapan sebagai tabungan untuk memenuhi kebutuhan yang akan datang termasuk untuk memenuhi kebutuhan anak-anaknya nanti.

Bukannya mereka tidak percaya pada Bank untuk menyimpan uang mereka, akan tetapi mereka malu menabung karena kesulitan menghasilkan uang dan juga untuk meminjam uang di Bank menurut merekaprosesnyayangterlaluribetdan harus meninggalkan barang jaminan serta batas waktu pengembalian yang ditentukan. Sedangkan melakukan pinjaman di Desa dengan mengikuti kegiatan banjar prosesnya mudah dan cepat serta tidak harus meninggalkan barang jaminan dengan batas pengembalian yang bebas sehimgga membuat mereka merasa cukup dibantu dengan adanya perjanjian hutang-piutang banjar tersebut.

Banjar terdiri dari banyak jenis kegiatan yang biasa dilakukan di masyarakat Lajut. Adapun jenis-jenis kegiatanbanjarmisalnyasepertibanjar beras, banjar uang, banjar kecimol, banjarkopi, banjar gula, banjarkelapa, banjar minyak goreng, banjar tepung, banjar padi dan banjar daging. Namun kaitannya dengan jenis kegiatan banjar peneliti memfokuskan untuk mengambil sampel pada kelompok banjar daging.

Praktek banjar daging dapat dibentuk oleh masyarakat yang ingin melaksanakan kegiatan banjar 
daging. Pertama-tama mereka membuat kesepakatan dan perjanjian yang disaksikan oleh orang-orang yang ingin ikut dalam kelompok banjar daging. Mereka menunjuk salah satu anggota sebagai ketua dan mencatat jumlah anggota yang ikut bergabung dalam banjar daging serta mengadakan perjanjian atau kesepakatan berapa jumlah daging yang akan dikeluarkan dan jangka waktu dikeluarkannya. Misalnya dalam jangka waktu setahun dana banjar boleh dikeluarkan atau orang yang akan mendapatkan dana banjar adalah dua atau tiga orang. Apabila dari anggota banjar tersebut terdapat lebih dari dua orang yang memiliki hajatan misalnya seperti anaknya menikah maka orang yang ketiga aturannya harus mengambil dana banjar tahun depan

Praktek Hutang-piutang dalam kelompok banjar berlaku dalam jangka waktu yang lama sehingga perlu dicatat supaya tidak terjadi kekeliruan di tahun yang akan datang, serta dapat dijadikan bukti siapa anggota yang sudah dan belum mendapatkan dana banjar. Kemudian karena jangka waktunya lama, maka apabila salah satu anggota banjar meninggal dunia, maka yang akan meneruskan atau yang akan membayar banjar tersebut adalah anaknya ataupun keluarga terdekat lainnya. Inilah sebabnya perlu dicatat untuk saling mengingatkan satu sama lain dan disertai dengan bukti ril yang telah tercatat, sehingga pada saat nanti ditagih untuk mengeluarkan iuran dana banjar tidak terjadi kericuhan. Pernyataan diatas sesuai dengan firman Allah SWT dalam Al-qur'an Surat Al-Baqarah ayat 282 tentang pentingnya pencatatan dalam setiap transaksi.

Artinya: $\quad H a i$ orang-orang yang beriman, apabila kamu bermuamalah tidak secara tunai untuk waktu yang ditentukan, hendaklah kamu menuliskannya. dan hendaklah seorang penulis di antarakamumenuliskannyadengan benar. danjanganlah penulisenggan menuliskannya sebagaimana Allah mengajarkannya, meka hendaklah ia menulis, dan hendaklah orang yang berhutang itu mengimlakkan (apa yang akan ditulis itu), dan hendaklah ia bertakwa kepada Allah Tuhannya. ${ }^{8}$

Penjelasan ayat di atas dengan secara tegas Allah SWT memerintahkan bahkan memberikan umatNya petunjuk bahwa apapun jenis transaksi yang dilakukan di dunia ini agar tetap mencatat jenis muamalat yang digeluti selebih-lebihnya tentang hal yang paling penting yakni hutang-piutang ini sangat membutuhkan pencatatan yang akurat dan bukti yang benar supaya

${ }^{8}$ Departemen Agama Republik Indonesia, Al-Qur'an dan Terjemahnya,. . . h. 70 
nanti tidak terjadi kesalahan dalam menagih hutang maupun pada saat ditagih dan manfaatnya untuk saling mengingatkan.

Kaitannya dengan ayat di atas dalam pelaksanaan praktek banjar daging atau hutang-piutang yang dilakukan masyarakat Desa Lajut Kecamatan Praya Tengah Kabupaten Lombok Tengah telah benar karena ketua banjar telah mencatat jumlah orang atau anggota kelompok yang ikutdalamkegiatanbanjarsertajumlah obyek atau barang yang dikeluarkan selama kegiatan banjar berlangsung, mereka sudah menerapkan perintah Allah SWT dalam surat Al-Baqarah ayat 282 tentang pencatatan hutangpiutang dalam bermuamalat, akan tetapi banyak juga yang menyimpang bahkanlupabahwa dalam pelaksanaan akad perjanjian hutang-piutang itu harus dilunasi, mereka menganggap hal tersebut sepele bahkan ada yang benar-benar tidak peduli terhadap hutang banjar tersebut.

Adapun pokok-pokok terpenting ataupun kaitannya dengan banjar daging dalam fiqih muamalah atau dalam hukum Islam bahwa kegiatan praktek banjar atau hutangpiutang ini banyak manfaat sosial yang terkandung didalamnya untuk masyarakat. Oleh sebab itu kegiatan banjar daging memiliki beberapa poin diantaranya:

\section{a. Banjar sebagai bentuk tolong- menolong}

Dalam hukum Islam kegiatan praktek banjar daging merupakan perbuatan tolong-menolong untuk saling meringankan beban sesama dan merupakan perbuatan atau akhlak terpuji dalam bermasyarakat apabila dalam kegiatannya tersebut terdapat saling peduli, rasa persaudaraan, toleransi yang memang sudah kewajiban kita sebagai mahluk ciptaan Allah yang saling berhubungan, hablumminannas yakni hubungan dengan sesama manusia.

Sumber ajaran Islam seperti Al-Qur'an sangat kuat menyerukan prinsip hidup tolong-menolong. Bahkan dalam Al-Qur'an disebutkan bahwa hutang-piutang untuk menolong atau meringankan beban orang lain seperti Firman Allah SWT dalam surat Al-Hadid ayat 11 yang berbunyi

Artinya: Siapakah yang mau meminjamkan kepada Allah pinjaman yang baik, Maka Allah akan melipat gandakan (balasan) pinjaman itu untuknya, dan dia akan memperoleh pahala yang banyak. ${ }^{9}$

Ajaran Islam tidak saling memberatkan satu sama lain bahkan haram hukumnya jika sesama umat muslimmemberatkanataumerugikan rekannya. Dalam Al-Qur'an tersebut

${ }^{9}$ Ibid., h. 902 
Allah SWT memberikan janji kepada hamba-Nya untuk melipat gandakan pahala atau harta yang diperhutangkan untuk membantu sesama manusia dan janji Allah SWT itu tidaklah bohong melainkan suatu kebenaran yang hakiki.

\section{b. Praktek banjar yang tidak mau membayar dana banjar (hutang-piutang) orang tuanya atau hutang yang diwarisi}

Islam mengajarkan kita untuk memperhatikan hutang-piutang kita terlebih hutang-piutang orang tua yang sudah meninggal dunia, karena beban hutang sangatlah berat apalagi yang berhutang tersebut meninggal dunia. Berkenaan dengan hal tersebut Islam memberikan solusi untuk hutang tersebut yakni hutang tersebut harus dibayarkan oleh orang yang masih hidup dikalangan keluarganya. Kemudian walaupun yang berhutang masih hidup namun tidak mampu untuk membayar hutangnya maka hutang tersebut boleh dipindahkan. Dalam hukum Islam hal ini dikenal dengan nama hiwalah (pemindahan hutang).

Kaitannya dengan banjar yang dilakukan oleh masyarakat Desa Lajut jika orang tua yang ikut dalam praktek banjar meninggal terlebih dahulu dan masih memiliki tanggung jawab hutangbanjarkepadakelompokbanjar lainnya maka yang membayarkan hutang banjar tersebut adalah ahli warisnya atau keluarga terdekat. Hal itu dilakukan berdasarkan ajaran Islam untuk tetap membayarkan hutang orang yang sudah meninggal dunia atau hutang tersebut dialihkan penanggungannya kepada ahli waris atau kerabat terdekatnya yang masih hidup seperti yang dijelaskan dalam hadits Rasulullah SAW.

"Dari Jabir ra. Ia berkata "telah meninggal dunia seorang lakilaki diantara kami, lalu kami memandikannya, mewangikannya (memberikannya kayu cendana) dan mengkafaninya, kemudian kami membawanya kehadapan Rasulullah SAW, lalu kami berkata "hendaklah baginda menyalatkan orang ini." kemudian beliau melangkah beberapa langkah, lalu bersabda "apakah jenazah ini punya (tanggungan) hutang?" kami menjawab "dua dinar." Maka beliau pergi, kemudian Abu Qotadah menanggung hutang dua dinar itu, lalu kami datang lagi kepada Rasulullah SAW dan Abu Qotadah berkata "hutangduadinar itu adalah menjadi tanggungan saya." Maka Rasulullah SAW barsabda "tetapkah (benarbenarkah) engkau menanggung hutang itu dan si jenazah bebas darpadanya?" $\mathrm{Abu}$ Qotadah 
menjawab "ya". Lalu Rasulullah SAW menyalatkan jenazah itu. ${ }^{10}$

Keterangan arti atau maksud hadits tersebut ialah menjelaskan bahwa hutang seseorang kepada orang lain itu tetap harus dibayar atau dilunasi meskipun orang yang berhutang keburu meninggal dunia dan belum sempat membayarnya, yakni oleh ahli warisnya atau orang yang mau menanggungnya.

Hutang-piutang ialah memberikan sesuatu kepada seseorang dengan perjanjian dia akan membayar yang sama dengan itu. Misalnya menghutang uang Rp 2.000.000, maka akan dibayar Rp 2.000.000 pula. ${ }^{11}$

Para imam mazhab sepakat apabila seseorang mempunyai hak pada oraga ting lain, lalu orang lain itu memindahkan pembayarannya kepada pihak ketiga, dimana ia mempunyai hak padanya, maka pihak ketiga tidak boleh menolak pengalihan hutang itu, dan tidak diperlukan keridoannya. Demikian pendapat imam Hanafi dan Safi'i. Sedangkan pendapat Maliki adalah jika pihak pertama adalah musuh bagi pihak ketiga, maka pihak ketiga tidak wajib menrimanya. ${ }^{12}$

${ }^{10}$ Ibnu Hajar Al-Asqalani, Terjemahan Bulughul Maram (Surabaya: Gitamedia Press, 2006), h. 421

${ }^{11}$ Sulaiman Rasjid, Fiqih Islam (Bandung: Sinar Baru Algensindo, 2010), h. 306

${ }^{12}$ Syaikh Al-Allamah Muhammad bin Abdurrahman Ad-Dimasyqi, Fiqih Empat
Melebihkan pembayaran dari sebanyak hutang, kalau kelebihan itu memang kemauan yang berhutang dan tidak atas perjanjian sebelumnya, maka kelebihan itu boleh (halal) bagi yang menghutangkannya dan menjadi kebaikan untuk orang yang membayar hutang. ${ }^{13}$

Para imam mazhab berbeda pendapat tentang kembalinya pihak pertama kepada pihak kedua jika ia tidak memperoleh pembayaran piutangnya dari pihak ketiga. Dalam hal ini, menurut mazhab Maliki adalah kalau pihak kedua menipu pihak pertama ketika ia membuat pemindahan pembayaran hutang dengan mengatakan bahwa ia tidak mampu membayar, dan hal itu diketahui dari pihak ketiga, maka pihak pertama boleh menuntut pembayaran kembali kepada pihak kedua. Adapun jika bukan disebabkan penipuan, ia tidak boleh menuntut pembayaran kembali kepada pihak kedua. Sedangkan pendapat Syafi'i dan Hambali adalah pihak pertama tidak boleh menuntut pembayaran kembali kepada pihak kedua secara mutlak, baik disebabkan penipuan maupun lainnya. Hal itu karena pihak pertama keliru, yaitu tidak membahas itu terlebih dahulu sebelum menerima pengalihan hutang tersebut. Dari Hanafi diperoleh riwayat bahwa

Mazhab, cet ke tiga belas (Bandung: Hasyimi), h. 261

${ }^{13}$ Sulaiman Rasjid, Fiqih Islam. . .h. 307 
pihak pertama kembali menuntut kepada pihak kedua jika pihak ketiga mengingkari pembayaran hutangnya. ${ }^{14}$

Berdasarkan uraian tersebut dapat kita lihat bahwa pentingnya bertanggung jawab terhadap hutang yang akan menjadi kewajiban untuk melunasinya, ajaran Islam dapat memberikan solusi atau kemudahan untuk pelunasan hutang jika memang benar-benar tidak ada harta atau peninggalan untukmelunaskannya, yakni dengan cara hiwalah, jadi tidak ada alasan bagi masyarakat Desa Lajut untuk tidak bisa membayar hutang banjar yang diikuti terhadap anggota yang lainnya.

\section{c. Tidak mau membayar hutang banjar karena tidak mempunyai uang atau harta untuk melunasinya}

Memberi hutang hukumnya sunah, bahkan dapat menjadi wajib, misalnya menghutangi orang yang terlantar atau yang sangat membutuhkannya. Memang tidak salah lagi bahwa hal ini adalah suatu pekerjaanyangamatbesarmanfaatnya terhadap masyarakat, karena tiap-tiap orang dalam masyarakat biasanya memerlukan pertolongan orang lain. $^{15}$

${ }^{14}$ Syaikh Al-Allamah Muhammad bin Abdurrahman Ad-Dimasyqi, Fiqih Empat Mazhab, h. 262

${ }^{15}$ Sulaiman Rasjid, Fiqih Islam. . .h. 307
Hutang-menghutangi menurut hukum Islam adalah akad untuk memberikan sesuatu benda, baik yang berupa barang atau jenis apa saja dari seseorang kepada pihak yang memerlukan. Biasanya terkait dengan perjanjian. Tentu saja hutang harus dikembalikan dalamjumlah yang sama. ${ }^{16}$

Hukum pinjam-meminjami adalah mubah bagi orang yang berhutang, dan sunah bagi pihak yang memberi hutang. Dikatakan sunah karena memberi pinjaman secara tidak langsung telah menolong orang lain yang benar-benar dalam keadaan mendesak. ${ }^{17}$

Islam juga mewajibkan sikap adil dengan melunasi hutang jika sudah sanggup membayarnya agar terlepas tanggung jawabnya, jika seseorang mampu membayar hutang tetapi ia tidak melakukannya, maka ia bertindak zalim. ${ }^{18}$

Adapun sangsi yang diterima didunia ini jika yang berhutang lalai membayar hutangnya, sesuai dengan sabda Nabi yang artinya "orang kaya yang menangguhkan hutangnya patut diumumkan atau dicemarkan nama baiknya dan dihukum. Adapun

${ }^{16} \mathrm{Abu}$ Fajar Al-Qalami \& Abdul Wahid Al-Banjary, Tuntuna Jalan Lurus dan Benar (Penerbit: Gita Media), h. 386

${ }^{17} \mathrm{Ibid}$., h. 387

${ }^{18}$ Yusup Qardhawi, Norma dan Etika Ekonomi Islam (Jakarta: Gema Insani Press, 1997), h. 188-189 
sangsi di akhirat sungguh sangat pedih karena hutang-piutang adalah urusan yang bersangkutan dengan manusia dan berdiri di atas hal yang tidak bisa ditolerir. Bertambah parah lagi seseorang mati dalam keadaan berhutang dan segala peninggalannya tidak bisa menutupi hutangnya. ${ }^{19}$ Ancaman terbesar terhadap hal itu ialah bahwa mati sahid fisabilillah meskipun tinggi kedudukannya tidak bisa menggugurkan beban dosa terhadap orang yang berhutang. Dalam Sahih Muslim disebutkan sabda Nabi SAW "semua dosa orang yang mati syahidakan terhapuskecuali hutang." ${ }^{.20}$ Bertambah berat lagi dosa seorang peminjam jika ia meminjam dari orang yang miskin, yang tidak mempunyai pembela, kedudukan dan kekuatan dalam menghadapi orang yang berhutang yang kuat dan zalim. $^{21}$

Adapun dasar hukum bagi orang yang tidak mau membayar hutangnya padahal ia mampu membayarnya adalah kelak ia akan mendapatkan ganjaran yang setimpal dan juga termasuk orang yang zalim, hal ini sesuai dengan hadits Rasulullah SAW yang artinya "Dari Abu Hurairah ra. Ia berkata "Rasulullah SAW bersabda, "orang yang sudah mampu membayar hutang tetapi tidak mau cepat-cepat membayar (melunasinya), itu adalah

\footnotetext{
${ }^{19}$ Ibid., h. 188

${ }^{20}$ Ibid., h. 188

${ }^{21}$ Ibid., h. 188
}

zalim dan barang siapa diantara kalian hutangnya diserahkan kepada orang yang sudah mampu maka terimalah itu." 22

Dengan demikian peneliti dapat melihat dari pendapat para mazhabitu bahwa tidak ada alasan apapun untuk tidak mau membayar hutang karena bukan masalah hukuman di dunia saja yang nampak di akhiratpun tetap dicantumkan hukuman bagi yang tidak mau membayar hutangnya.

Praktek banjar daging yang dilakukan masyarakat di Desa Lajut memang berakhir cukup lama akan tetapi sebagai masyarakat atau tetangga yang baik dan memiliki sifat tanggung jawab terhadap hutang untuk benar-benar memperhatikan hutangnya dengan bahan pertimbangan takut terhadap siksaan di akhirat nanti seperti apa yang sudah dijelaska di atas mengenai hukuman yang akan diterima jika tidak melunasi hutang.

\section{d. Keluar dari konteks kerjasama banjar (hutang- piutang) secara sepihak atau mengundurkan diri}

Dalam hukum Islam tidak boleh keluar sebelum berakhirnya akad atau terjadi salah satu pihak yang dirugikan. Akad perjanjian boleh berakhir apabila akad tersebut memiliki tenggang waktu. Karena

${ }^{22} \mathrm{Ibnu}$ Hajar Al-Asqalani, Terjemahan Bulughul Maram. . . h. 421 
banjar ini bersifat mengikat akad banjar bisa berakhir apabila akad itu pasif, berlaku khiyar syarat, khiyacapai tukad, dan telah terr aib, akad tersebut tidak dilaksanakan oleh salah satu pihak yang berakad, dan telah tercapai tujuan akad secara sempurna.

Orang atau anggota banjar yang keluar dari praktek tersebut sebelum berakhir supaya tidak menimbulkan konflik harus tetap membayar kepada anggota yang lain, kecuali orang yang ikut dalam praktek banjar tersebut hilang, entah hilangnya kemana atau berada di luar negeri dan tidak ada keturunannya atau keluarganya yang akan melunasi hutangnya maka boleh untuk tidak membayar. Hal ini sesuai dengan Firman Allah SWT dalam surat Al-Syura ayat 41

Arttinya: Sesungguhnya orangorang yang membela diri sesudah teraniaya, tidak ada satu dosapun terhadap mereka. ${ }^{23}$

Maksud yang hutang-piutang ini sama maksudnya dengan perjanjian pinjam-meminjami. Hal ini dapat dijumpai dalam ketentuan kitab undang-undang hukum perdata pasal 1754 yang berbunyi "pinjammeminjam adalah suatu perjanjian dengan nama pihak yang satu memberikan kepada pihak yang lain dengan suatu jumlah tertentu

${ }^{23}$ Departemen Agama Republik Indonesia, Al-Qur'an dan Terjemahnya, . . h. 789 barang-barang yang menghabiskan karena pemakaian dengan syarat bahwa pihak yang belakangan ini akan mengembalikan sejumlah yang sama dari macam dan keadaan yang sama pula." ${ }^{24}$

Dalam kaitannya dengan praktek banjar daging yang dibuat oleh masyarakat Desa Lajut bahwa setiap anggota banjar terutama yang sudah mendapatkan giliran harus bertanggung jawab atas apa yang telah disepakati yaitu dengan membayar hutang atau mengeluarkan dana banjar sampai kegiatan tersebut selesai sehingga tidak terjadi konflik karena adanya anggota yang merasa dirugikan atau kecewa, dengan begitu apa yang telah dipraktekan tersebut mencapai tujuannya yakni untuk saling tolong-menolong dalam mencukupi kebutuhan hidup.

Ada beberapa hal yang perlu diperhatikan dan dijadikan takaran dalammelaksanakankegiatanhutangpiutang ialah sebagai berikut:

Pertaman sebagaimana yang terdapat dalam Qur'an Surat AlBaqarah ayat 282, bahwa hutangpiutang supaya dikuatkan dengan tulisan dari pihak berhutang dengan disaksikan dua orang saksi laki-laki atau dengan seorang saksi laki-laki dengan dua orang saksi perempuan. Untuk dewasa ini tulisan tersebut

${ }^{24}$ Chairuman Pasaribu, Hukum Perjanjian Dalam Islam (Jakarta: Sinar Grafika, 2014), h. 136 
dibuat di atas kertas bersegel atau bermatrai

Kedua, Pinjaman hendaknya dilakukanatasdasaradanyakebutuhan yang mendesak disertai niat dalam hati akan membayarnya.

Ketiga, Pihak berpiutang hendaknya memberikan pertolongan kepada pihak berhutang. Bila yang meminjam tidak mampu mengembalikannya, maka yang berpiutang hendaknya membebaskannya.

Keempat, pihak yang berhutang bila sudah mampu membayar hutangnya, hendaknya dipercepat pembayarannya karena lalai dalam membayar hutang berarti berbuat zalim $^{25}$

Hal yang demikian ini perlu peneliti tegaskan bahwa untuk menjalankan peran sebagai mahluk sosialyangtidakbisalepas daribantuan orang lain untuk tetap menjaga etika dalam bermasyarakat, sebab dengan menjaga etika akan menimbulkan keharmonisan ditengah masyarakat sehingga konflik sosial itu tidak akan pernah ada. Maksudnya disini peneliti memberikan gambaran umum supaya tetap menjaga kepercayaan antar sesama apalagi dengan pembentukan kelompok banjar daging yang identik dengan hutang-piutang. Hutangpiutang dalam bentuk banjar daging

${ }^{25} \mathrm{Hendi}$ Suhendi, Fiqih Muamalah (Jakarta: Raja Grafindo Persada), h. 98 di Desa Lajut ini terbentuknya sudah cukup lama dan berakhir cukup lama juga oleh sebab itu perlunya menjaga etika dalam berhutang dan menerapkan sistim syariah yang sesuai dengan ajaran Islam dan berpegang teguh pada kitab AlQur'an sebab didalamnya sudah jelas diterangkan mengenai tata cara dalam bergaul, bermuamalat yang benar dan sesuai dengan syariat Islam.

Berkenaan dengan pendapat para Imam mengenai pengertian Alqardh pada bab sebelumnya, maka kegiatan kelompok banjar daging yang dilakukan oleh masyarakat Desa Lajut bisa dikategorikan sebagai bentuk transaksi hutangpiutang (al-qardh) karena dalam pelaksanaannya mereka memberikan barang kepada anggotanya berupa daging atau uang sesuai dengan yang telah disepakati yang pada suatu saat akan dikembalikan. Namun dalam pelaksanaannya yang rill, masyarakat Desa Lajutbelum sepenuhnya mampu melaksanakan sesuai dengan konsep al-qardh yang telah disyariatkan agama islam.

\section{KESIMPULAN}

Berdasarkan uraian yang sudah dipaparkan dari bab 1 sampai dengan bab 3 dapat disimpulkan beberapa poin tentang implementasi konsep AlQardh padakelompokbanjardagingdi Desa Lajut Kecamatan Praya Tengah Kabupaten Lombok Tengah. Bahwa 
di desa Lajut konsep Al-Qardh atau hutang-piutang di implementasikan dengan cara membentuk kelompok banjar daging yang tujuannya untuk saling tolong-menolong dalam rangka memenuhi beban kebutuhan hidup. Dimana bentuk yang dikeluarkan adalah dalam bentuk daging atau uang namun dihargakan dengan harga daging yang jumlahnya disepakati bersama. Sistim hutang-piutang dalam bentuk banjar daging yang dilakukan di Desa Lajut terdiri dari 3 kelompok yaitu kelompok banjar daging $2 \mathrm{~kg}, 3 \mathrm{~kg}$ dan $5 \mathrm{~kg}$. Dimana dalam pelaksanaannya tidak seperti sistimhutang-piutangyangditerapkan di perbankkan yang memakai jaminan dan bunga serta masa tenggang waktu, hanya didasarkan pada kepercayaan masing-masing anggota. Kegiatan praktek banjar yang dilakukan oleh masyarakat Desa Lajut tersebut sedikit menyimpang dari tatanan ajaran Islam dimana hal-hal yang menyimpang tersebut seperti tidak mau mengeluarkan atau membayar hutang banjar padahal dulu sudah mendapatkan giliran dan mendapatkan dana banjar tersebut, ada juga yang keluar sebelum akad banjar berakhir atau semua anggota belum mendapatkan giliran dimana haltersebutmengakibatkanterjadinya konflik yang berkepanjangan.

\section{DAFTAR PUSTAKA}

Abdurrahman Fathoni. Metodologi penelitian \& teknik penyusunan skripsi. Jakarta: Rineka Cipta, 2005.

Abu Fajar Al-Qalami \& Abdul Wahid Al-Banjary. Tuntuna Jalan Lurus dan Benar. Jakarta: Gita Media, 2010.

Ahmad Wardi Muslich. Fikih Muamalat. Jakarta: Amzah, 2015.

Andini T, Nirmala dan Aditya A. Pratama. Kamus Lengkap Bahasa Indonesia. Surabaya: Prima Media, 2003.

Beni Ahmad saebani. Metodepenelitian. Bandung: CV Pustaka setia, 2008.

Chairuman Pasaribu. Hukum Perjanjian Dalam Islam. Jakarta: Sinar Grafika, 2014.

Departemen Agama RI. Al Qur'an dan Terjemahnya. Jakarta: Depertemen Agama, 1985.

Dimyauddin Djuwaini, Pengantar Fikih Muamalah, Jakarta: Pustaka Pelajar, 2010.

Ghufron A. Mas'adi. Fiqih Muamalah Kontekstual. Jakarta: Raja Grafindo Persada, 2002.

Hendi Suhendi. Fiqih Muamalah Jakarta: Raja Grafindo Persada, 2012 
Ibnu Hajar Al-Asqalani. Terjemahan Bulughul Maram. Surabaya: Gitamedia Press, 2006.

Ibnu rusyid. Baitul Mujtahid IV. Jakarta: Pustaka Amani, 1995.

Ismail Nawawi. Fikih muamalah Klasik dan Kontemporer. Bogor: Ghalia Indonesia, 2012

Kang Mahfudz, "Ilmu Qur'an dan Tafsir", dalam http// Ibmnulampung.blokspot, diambil Tanggal 27 juli 2016, Pukul 12.36 WITA.

L. Muh. Taisir. Pandangan Hukum Islam terhadap Kerjasama (Syirkah) di Desa Sepit Kec. Keruak Kab. Lotim. STAIN Mataram: 2002.

Madian Rubana. Dimensi-Dimensi Ekonomi Islam dalam Praktek Pembagian keuntungan pada kerja sama Pembuatan Batu Bata di Desa Bare Julat Kecamatan Jonggat Kabupaten Lombok Tengah. STAIN Mataram: 2002.

Maleong. Metodelogi Penelitian Kualitatif. Bandung: Remaja Rosda Karya, 2007.
Nurul Zuriah. Metodologi Penelitian Sosial dan Pendidikan TeoriAplikasi. Jakarta: Bumi Aksara, 2006.

Sugiono. Metode Penelitian Kombinasi. Bandung: Alfabeta, 2012. - Metode Penelitian Kualitatif dan R\&B. Bandung: Alfabeta, 2007.

. Metode Penelitian Kuantitatif Kualitatif dan R\&D. Bandung: Alfabeta, 2014.

Sulaiman Rasjid. Fiqih Islam. Bandung: Sinar Baru Algensindo, 2010.

Syafiq Hanafi, Sistim Ekonomi Islam dan Kapitalisme. Yogyakarta: Cakrawala, 2007.

Syaikh Al-Allamah Muhammad bin Abdurrahman Ad-Dimasyqi. Fiqih Empat Mazhab. Bandung: Hasyimi, 2006.

Utang Piutang Dalam Hukum Islam_ BMT Azka Patuk Gunungkidul. htm

Yusup Qardhawi. Norma dan Etika Ekonomi Islam. Jakarta: Gema Insani Press, 1997. 